Auction 110

The Brinkley Collection Art Gallery of Edward Green
1886 
: intoj "vojpsots : $\lambda$ "N 'esnjodks

y3aNI 137HdWVd 

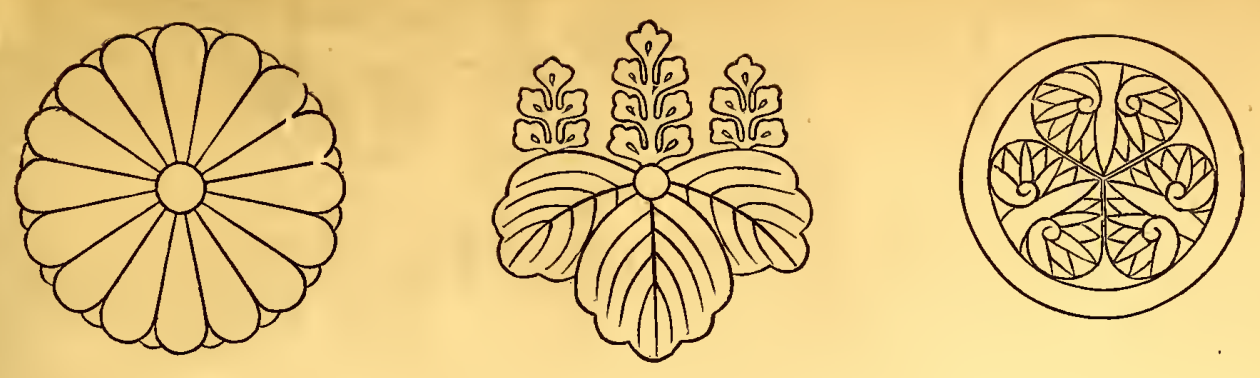

THE

B R I N K L E Y

COLLECTION

(8)

\author{
ART GALLERY \\ OF \\ EDWARD GREEY
}

NEW YORK

TWENTY EAST SEVENTEENTH STREET

M DCCC LXXXVI 
$O^{F}$ the large number of descriptions of the Brinkley collection that have appeared in various journals, the following, by a well-known art writer, is, from an artistic standpoint, the best that has been written by a woman. EDWARD GREEx.

Art Gallery, 20 East I7th Street,

New York. 


\section{THE BRINKLEY COLLECTION}

[REPRINTED FROM THE ART AGE OF JANUARY, I 886]

$\mathrm{T}$

He Brinkley historical collection of antique Japanese, Chinese and Korean porcelain pottery and faience, lately purchased by Mr. Edward Greey, the accomplished Oriental specialist, and now on exhibition at his art gallery, 20 East Seventeenth street, is the most complete and valuable ever shown in this country. It was formed by Captain F. Brinkley, of Yokohama, Japan, for his own pleasure as a connoisseur, and to assist him in writing an important work, a History of Japanese Keramics, which will soon be published by a leading New York firm. Captain Brinkley is the greatest English authority on Japanese Keramics. His collection, formed, as it largely is, of treasures purchased from Japanese men of rank, who had fallen upon evil times, was celebrated among Japanese connoisseurs, who regarded with sorrow the departure of so many historic and classic examples of the potter's art from the empire of the chrysanthemum. Many of these superb objets d' art belonged to the distinguished Japanese keramist, Ninagawa Noritane, who was a friend of Captain Brinkley. Every piece of porcelain, pottery or faience in this collection is of great intrinsic value. From the historic ind artist1c standpoint, the collectivis, a whole, is priceless. Nowhere else in the world can the rise, progress and development of ancient Japanese Keramic art be as effectively and exhaustively studied as in this collection as it now stands in Mr. Greey's gallery. It is absolutely pathetic to feel that this apotheosis of keramic art must so soon dissolve and disappear, that bit by bit the collection must be scattered broadcast over the land. It should be bought en bloc by some public art museum, to serve as an educational influence for American workers in pottery and amateurs of keramics.

Its present owner has arranged the collection so skilfully that the historical relations of the different kinds of porcelains and potteries are preserved and emphasised, while the artistic effect of the whole, as to color, form and tone, is strongly felt by the spectator upon entering the consistently decorated gallery. The Japanese department occupies half of the large room, the Chinese and Korean department the other half. The delicate beauties of the Japanese porcelains, the small, brilliant color-masses of the Japanese faiences are seen in the daylight, which brings out sharply the subtle, iridescent tones of their wonderful glazes. The light reaches them through windows shaded by Japanese fretwork and draped with sage-green crêpe curtains, figured with soft reds. The larger masses, the stronger outlines, the more intense lustres of the Chinese and Korean porcelains and potteries receive the artificial illumination which is best adapted to throwing their perfections into relief and deepening their glow of color and tone. The Chinese celadons, crackles and whites in the case at one end of the room, form a mass of pale color in a light key. One side of the room is rich, dusky and lustrous in color and deep in tone, with its magnificent polychromatics and mirror-blacks. The side opposite it has the superb collection of blue and white forming a lighter mass of color, relieving the more complex chromatic effect of the Chinese painted porcelains, the robust Korean stone-wares and the lovely Korean ivory-whites.

In the Japanese department, the case of Satsuma is placed at the end of the room between the two windows, and forms a keynote of tone and color for that part of the collection. Speaking broadly, the porcelains occupy the cases on one side of the room, the faiences those on the other. The blue and whites form a delicate mass of color which is in no wise injured by the greater strength of the neighboring case of brilliantly tinted enamels. A thousand

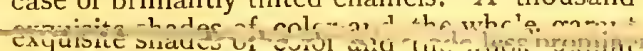
of tone are found in the collection of faiences on the opposite side. The idea of color-harmony is carried into the disposal of the smallest pieces. The cases in which these keramic jewels sparkle and burn, as if with imprisoned fires, are framed in gray wood made to imitate the Japanese cedar taken from the bogs. The cloth linings are of soft Japanese red. The dado under the cases is of gray matting, delicately threaded with red. The carpet is pale red. The friezes are formed by the rich, dusky brocades worn in Japan as women's girdles. Their bronze-green and dullgold tones repeat admirably the color-notes of the porcelains.

A small room, which contains large Chinese monochromes and polychromes, has strong effects of color and light. Blue is the prevailing hue of the decorations, and the large blue splashes which stand in a row against a background of gold brocade give the chromatic keynote. Either side the splashes is a jar of white decorated porcelain, which repeats the whites of the wall hangings, especially those in the large picture of Buddha, which occupies a vacant space. The window is shaded by pale blue crêpe curtains, figured with delicate red branches, but they are not allowed to interfere with the strength of the daylight. A finer sight can not be imagined than that presented by this noble and stately procession of celadons, with the 
broad daylight striking full upon their rich, pure surfaces, which recall the opaque green pallor of Venetian twilight skies. History tells us that one of the Chinese Emperors bade his keramists study the color of the skies as they appeared after rain, and the result of their study was the glaze of the celadon. In the celadon, keramic magnificence reaches its apogee of color and decorative splendor.

Returning to the Japanese room the visitor should begin the study of the collection in detail with the case of blue and white porcelain. Japan was indebted to China for the art of manufacturing this kind of porcelain, and the potter who introduced it into Japan was one Gorodayu Shonzui, who, in I 510 , went to China in pursuit of knowledge. After five years he returned to Japan, bringing with him Chinese clay, glaze and colors. He settled at Arita, a village in the province of Hizen, and produced porcelain modeled after the specimens of blue and white, which he had seen in China. He imparted, however, greater naturalness to the decoration. The celebrated hawthorne, or properly plum-blossom pattern, is attributed to him, and it is probable that his works and designs were copied, not only by his Japanese followers and pupils, but by the Chinese. Shonzui's position, as the father of the Japanese porcelain manufacture, makes work from his wheel particularly valiable from the historical standpoint. This collection contains four pieces by him, a tea jar (No. I), a plate (No. 2), a pair of wine bottles (No. 3), and a tube for holding a tea-

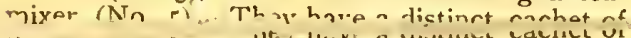

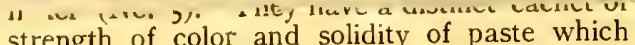
makes it easy to identify them. All show the diaper pattern, and are decorated in small masses. The blue is very brilliant, having, with the clay of which they are composed, been imported from China by Shonzui. Japanese blue and white porcelain, as may be seen by comparing the two cases in this collection, differs from the Chinese in being paler and more delicate in color, tone and general effect. The Japanese decoration is less conventional and more artistic. It follows nature closely and employs the natural forms as slightly conventionalised as the exigencies of decoration allow.

An interesting and valuable piece is a wine bottle (No. 5), which is a Chinese imitation of Shonzui's work. A link in the chain of Japanese keramic development is a stoneware tea jar (No. 6), by Goroshichi, a pupil of Gorodayu Shonzui. This piece represents the period between the exhaustion of the supply of clay brought from China by Shonzui, and the discovery, in the neighborhood of Arita, in Hizen, where the factory was, of clay suitable for porcelain. This discovery was made by a Korean keramist, one Risampei, whose influence on the Japanese porcelain manufacture was very great. It may be said that the keramic art of China entered Japan by way of Korea.

The Imari blue and white porcelain, which takes its name from Imari, the seaport nearest Arita, is represented by a number of valuable examples. In this ware, as in the Hirado and Mikouchi porcelains, the blue is under the glaze. A set of ten cups of Imari porcelain (No. 72) is beautifully decorated with landscape and plum-blossom designs. Another fine specimen of Imari is a cylindrical water holder, designed in sky-lions and peonies, very delicate in tone and color (75). The finest of all the Japanese porcelains in quality of paste and beauty of decoration is the Hirado blue and white. The delicate milk-white glazes form an exquisite background for the tender, almost ethereal blues of the decoration. The forms of the designs are very lovely, and so daintily realistic is their aspect that they seem to have come from the hand of nature herself, rather than from that of the potter. An important piece in this collection is a flower vase (No. 8o), the globular body of which is covered with landscapes, carefully painted after the Chinese manner. The handles are white and represent elephant heads. A cakebox (No. 82), with a band of waves raised in the paste round the base, a flight of storks in blue about the body and a tortoise on the lid, is purely Japanese in its decoration. Unusually beautiful is the bamboo decoration in blue of a water-holder (No. 84). A valuable specimen of the porcelain is a plate decorated with five medallions of the Tokugawa crest, (three leaves) and willow boughs, the whole forming a consistent and artistic decorative scheme (No. 93). A bowl (No. 94) with blue crabs- painted on it is exceptionally pure and fine in point of pâte, and the conception and execution of the crab design shows the Japanese painter-decorator at his best. A unique cloveboiler has a pierced lid and decoration in blue in the paste, somewhat in the fashion of the Chinese grains of rice pattern, but raised instead of being sunken (No. 97). One of the most interesting and important examples of the porcelain is a sparrow used for holding water to be dropped on ink slabs (No. 98). The glaze is wonderfully brilliant and the blue decorations, representing plums, bamboos and pines, are charmingly treated. A very beautiful plate in the form of a peony leaf is decorated simply with three blue butterflies of exquisite workmanship (No. IOI). An unusually good example of the larger Hirado blue and whites is a vase decorated with drooping willow branches and with conventionalised waves in blue. The handles are shaped like frogs. This is one of the most important pieces in the blue and white case. A great deal of beautiful pierced work is found among the Hirados. This case contains five examples of eggshell blue and white from the Mikouchi kiln. Especially fine are a bowl designed in carp and water grasses (No. I08) and one in which birds, flowers, landscape and verses enter into the decoration (No. I I I).

Among the white Hirados are to be seen some admirable pieces. A cylindrical water- 
holder, with relief work of peonies and leaves (No. I12), an incense-burner in the form of a seated devil (No. I I5), a dragon (No. I I4), a sky-lion with a ball (No. 122), and another dragon (124). All of these objects are noticeable for purity of the paste and glaze, and for their fine modeling, which gives them the effect of sculpture. One of the largest and most important examples is found in the two pieces (124A), one of which represents a man on horseback, in an attitude of attack, with a figure under the horse's hoofs. The other shows a man in a pose of defence and supplication. The relation between the two pieces is remarkably well expressed. The figures are full of action, and the modeling is firm and decided. The texture of the glaze is very united in effect, and the pieces are strikingly pure in color. A beautiful example of open work is presented by a circular incense-burner ( 116 ), with two panels containing the three leaves of the Tokugawa crest. Among the colored Hirados two numbers are particularly worthy of attention. One is a flower vase in the shape of a clump of bamboos, with the

$125-155$ Seven Sages at the base (No. 125), and the other shows an eagle perched on a rock (No. I28). Both are painted in the natural colors, and have a pictorial and life-like appearance. A splendid specimen of white Hizen, the only one in the collection, is a wine bottle of a gray tone, which has somewhat the effect of a sponge, and is highly decorated with floral and animal 131-189 motives (13I).

The Imari or Hizen porcelains, decorated with enamels over the glaze, were evolved trom the blue and white Imaris which were produced by the school of Shonzui; but neither Shonzui, his pupils, nor the Korean Risampei succeeded in carrying the Japanese keramic decorative scheme beyond the point of painting in blue under the glaze. It was not until Tokuzayemon went from Arita, in the Hizen province, to Nagasaki, and there learned the Chinese secret of applying colored enamels over the glaze, that this form of decoration was introduced into the Japanese porcelain manufacture. The Japanese potters did not, however, servilely follow the conventional Chinese decorative forms. They adapted them to their own artistic uses and greatly improved upon them. All the Japanese enamels show a beauty of color and a knowledge of chromatic combinations which are entirely individual. The metallic reds, the bright greens, the golds and lilac purples of the Hizen enamels, when combined with the fundamental blue under the glaze, form a color-scheme unrivalled for delicate brilliancy. The effect of the Hizen enamels is that of old brocades, and their colors were undoubtedly combined in imitation of the designs found in those precious stuffs. This collection contains a large riumber of magnificent Hizen enamels, arranged so as to give them their full value of color.

A large trumpet-shaped flower-vase, deco- rated with flowers, sky-lions, diapers in blue, green, red, gold and black (No. 7); a jar decorated in strong colors and large masses, with landscape, tree and flower motives (No. 8), and another jar (No. 9) in which gold is freely used in the decoration, are among the largest and finest specimens. The dishes and bowls are very beautiful. They are particularly rich in their greens, blues and purples. Nos. 15, I7, I9 and 20 are magnificent pieces of color. No. 25, a round bowl, is designed in diapers of purple and green, and is at once vigorous and delicate in color. No. 39, a bowl with lid, is exceptionally fine in quality of paste and in the unusual character of its charming decoration, which consists of brilliantly colored sparrows and medallions with leaf-scrolls. No. 55 is a set of ten blue cups in the form of bundles of reeds, bound with red and gold cords and decorated with red and gold cherry blossoms.

Two finely decorated pieces are the waterholders, Nos. 59 and 6o. The culmination of the Japanese porcelain enamel art is represented by a wine-kettle, decorated-almost coveredwith brilliant reds, golds and other colors in medallion and diaper patterns. From the presence of the conventionalised chrysanthemum on the knob of the lid and round the base of the knob it is probable that this superb piece belonged to the imperial family of Japan (No. 69). The celebrated Nabeshima porcelains, decorated with colored enamels and blue under the glaze, are represented by a number of valuable objects. In general effect of color they resemble the other Hizen enamelled porcelains, but the blue under the glaze is made less prominent. Among the Nabeshima celadons is a large vase, with a band of figures under the glaze, and panels containing key-patterns and archaic designs (I43). This specimen of Japanese celadon fully justifies the claim made for this ware, that it almost equals the best Chinese celadon.

The collection of Satsuma faience is unequaled by any other in the world for beauty, value and rarity. It includes enameled pieces and monochromes. Among the gems of the entire Japanese collection is a Satsuma vase decorated with plum, bamboo and pine designs. It is the largest piece of old Satsuma known to exist (No. I7 I). No. I 45, an incense-burner, with floral and geometrical decorations, is a sumptuous piece of ware. A paper weight, in the form of camelia leaves and bud, covered with green and blue glaze, is beautiful in form and color and in the quality of the glaze (I53). An uncommonly fine example of the old ivory-white Satsuma so highly valued by connoisseurs is a vase (No. 160) which is singularly beautiful in form and color. An incense burner with a silver lid (No. I6I) and two cups (Nos. 162 and I63), are specimens of the best Satsuma.

The department of Kyoto faiences is very valuable and interesting, containing as it does a large number of representative examples of the different kilns. Foremost in historic interest
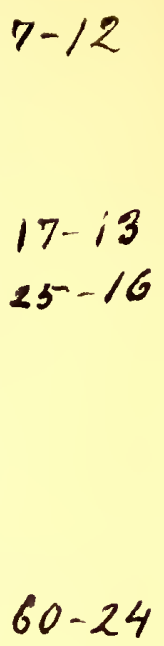

$133-178$

$160-81$ 
stand the pieces executed by Nomura Ninsei, the father of the Japanese enameled faience manufacture. Ninsei was a Japanese amateur worker in keramics, who, becoming possessed of the precious secret of enameling porcelains, transferred the process to faience. The impulse he gave to the faience manufacture in or near Kyoto produced a new school of keramics. His decorative system became a national one, and the ideas which originated with him and were developed by his pupils resolved themselves into leading keramic principles. The faience factories of Awata, Fukakusa, Kiyomizu, Iwakura and Mizoro were established by the pupils of Ninsei and were influenced by his productions.

The six examples of Ninsei's own work are of very great value. They are a vase partly unglazed and partly glazed in russet, black, white and blue (No. I73); an incense-burner (No. I74) with a pierced lid, crackled in the manner peculiar to Ninsei, as is also a cup, adorned with four circular medallions (No. I75); an incense holder, in the shape of a mallard duck, fine in color, in glaze and in crackle (176); a tea jar with round crackles (177), and a waterholder, very rich in the tone of the glazes.

Among the Awata faiences all the different kinds of keramic work produced by this celebrated kiln are fully exemplified. Nos. I79, I 80 and I8I show what the Awata potters were capable of in the line of pictorial figure work. These little grotesques are full of life and action, and follow nature closely in form and color. A fine piece of work is the figure of the poet H'tomaru!' $3 x$ cellent in color and delicately crackled. All the Awata wares are very decorative in effect, especially those attributed to Kinkozan. No. 203, a clove-boiler; 207, a wine bottle; No. 208, a clove-boiler, and others of the same group are remarkable for their rich, heavy glazes, which in color remind one of jeweled glass. Another class of Awata faiences testifies to the influence exercised by the Dutch upon Japanese keramic art. No. 212 is an imitation of Delft ware. It has a beautifully soft bodyglaze of a dark buff, with blue landscapes under the glaze. It is very fine in tone. A similar piece is the wine bottle, No. 2r4. Even more Dutch in treatment is the wine vessel (No. 215). An oblong dish (2I6) is cleverly decorated after the Delft manner. The bowl (217) is a fine piece of ware. A superb example of enameled pierced work is the large cake-holder (No. 23I q).

An important specimen of Fukakusa ware is the figure of an old man sitting on a sudzu or temple bell, which he is polishing. It is the work of Koyemon, and very old. Among the pale, softlytoned Kiyomizu pieces may be particularised an incense box, with light green body-glaze (No. 238), an incense-burner in the form of a priest (240), one in the form of a lion (241), another in the form of Hotei (244), a Japanese god, and a delicately wrought pagoda in dark brown and pale glazes, which is used as an incense-burner $(245 \mathrm{~A})$. Anıong the Iwakura faiences, with their fine creamy body-glazes, the monochrome cake box of pierced work commands attention (No. 247). A cup (248), glazed in dead leaf color, with light brown and black decorations, is very characteristic. Strong, brilliant colors mark the decorative scheme of the Mizoro ware. A wine bottle (255) has a beautiful green bodyglaze, richly enameled. A pair of wine bottles, with grayish-white body-glaze $(256)$ and an incense box shaped like a chrysanthemum, with a pierced lid (257) are splendid pieces of the ware.

No one of the many Japanese faiences possesses more decorative quality than the Eiraku ware, so called after the name applied to the potter who perfected the process of its manufacture and invented its most brilliant glazes. This potter's real name was Zengoro Hozen. One of his most characteristic glazes is the coral red which, combined with gold, gives many of his works great value, and causes them to be classed among the masterpieces of keramic art. A magnificent example of this coral red and gold enamel is a wine bottle in the shape of a pomegranate (26I). A white and gold incense box, with a chrysanthemum on it, exemplifies another form of the ware. The color of Eiraku ware is generally peculiarly strong, rich and deep, and is applied in large masses. A vigorous piece of color is a fire-holder, with a green body glaze (No. 267). The fire-holder (268), the bowl with cover (260), the bowl with spreading neck (270) the bowl with pedestal (27I), and the tea jar (No. 272), are all magnificently glazed in purples, greens and yellows. They are all the work of Zengoro Hozen.

A beautiful piece of Akahada is a pale creamcolored crackled cup, richly enameled (No.292). Another fine example of Akahada is a basketshaped cake holder, in gold, green and white (No. 295). Among the Kenzan faiences, No. 296, a jar brilliantly decorated with leaf motives and an incense box designed in black scrolls and diapers (298) are especially noteworthy. A beautiful warmth of tone is noticeable in a Raku cup with black, red-veined glaze (300), and in an incense box of the same ware, which has a brownish white glaze. A cake box of Raku ware has the unique design of the god Hotei seated on a bag, from which infants' souls, like little grains of corn, are protruding in a mass (No. 504). A set of Raku chessmen in pale colors, forms an interesting study (No. 305). A fine old piece of Kutani is a plate in which green and yellow are the prevailing colors of the glaze (No. 308). A similar example, equally decorative, is the dish (306). A green wine bottle, decorated in black diapers under the glaze, is quite unusual in character (No. 3I3). A porcelain bowl, beautifully decorated (32I), and a plate (337) are among the-gems of the Kutani collection. The Imbe or Bizen pieces, Nos. $343,344,1345,347,349,1350$ and 351 ,

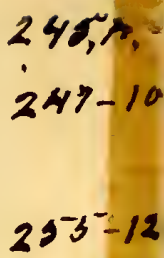

$255^{-}-12$ $297-12$

. (1) 
are of peculiar interest to connoisseurs. No. 347 is singularly beautiful, with its metallic glaze producing a mica effect. Among the sober, solid Higo pieces, with their deep-toned glazes, may be mentioned a shallow bowl in brown and white, designed with mystic astronomical characters and imitating Korean ware (352). Two vegetable bowls, glazed in brown, with a decoration of rice windbreaks in white, are fine in their simplicity of effect and unity of

$60-10$ the glaze (360). Valuable Banko pieces are numerous. Very noteworthy are a dragon bowl $7-46(363)$, a wine holder with a brilliant green body glaze $(367)$, a candle stick with a grayish white body glaze, crackled and decorated with red $83-131$ (370). There are five examples of the Awaji kiln, including a porcelain figure of Oto Gozen (373) and a beautiful porcelain incense-burner, covered with a crackled yeilow glaze (375). Ten examples of Izumo show the characteristics of the ware to advantage. Among the wares of the Takatori kiln is a particularly fine figure of the god Fukurokujin, used as an incense-burner, which is covered with with a rich brown, blue and green glaze (392). Other remarkable examples are a figure of a Chinese sage (388) and an incense burner in form of an owl with red and green glazes, Kishu ware is celebrated for the richness of its glazes, which was the result of the visit of the celebrated Keramist, Zengoro Hozen, to the kiln. Green, blue and purple in large monochromic masses were the favorite glazes. There are six examples of this ware, all beautiful as works of art and intrinsically valuable. Nu. $39^{\circ}$ is a vase with celadon glaze, designed in incised and relief work. No. 399 is a green glazed figure of a genius and a rat. No. $40 \mathrm{I}$ is a bowl covered with masses of purple and turquoise blue glaze, and $402 \mathrm{~A}$ is a splendid specimen of celadon glaze. Among the Sanda (celadon) stone ware 3 pieces are a figure of Hotei (403), a beautifully decorated vase (404) and a bonbon box (406). The three numbers which represent Tamba ware (pottery) are a tea jar, glazed with mottled brown and black (407), two wine bottles in fine, unglazed clay, decorated with storks in white and black (408), and a vase with a black bodyglaze, with faint, silver lines. One of the most interesting wares is the Seto, from its antiquity and its association with the early history of Japanese keramics. A number of these fine old pieces are to be seen in the collection. The Koto porcelains (blue and white) contribute a splendid mass of color to the case of Japanese old blue and white in the shape of a large figure of the god Hotei, the St. Nicholas of Japan, with his bag full of good things. The glaze is very pure in quality and the blue is of good color. The bag is modeled with extraordinary skill. It is in a blue diaper pattern (428). Another example of Koto of a different character is a flower vase (No. 430). The two examples of Himeji porcelain are a vase (43I) and a wine bottle (432), both decorated with blue under the glaze.
Every example of Japanese keramic art finds its prototype in the Chinese department, which is particularly rich in celadons, plain whites, crackles, polychromatic ware and Kienyo bowls. The blue and whites also form a collection of unrivaled beauty and value. Among the plain whites is a very thin ivory-white porcelain bowl of great beauty of paste (449). Remarkable for fine modeling and the superior quality of the glaze is an ivory-white figure of the goddess Kwannon and child (456). A superb vase, illustrating the use of a different kind of glaze and preserving the old Chinese forms, is numbered 458 .

Among the crackles, which are of great rarity and value, may be specially mentioned a delicately crackled vase with a creamy glaze $\left(46_{3}\right)$; No. 465 , a vase very boldly crackled in circles with incised key pattern; a beautiful vase $(467)$ with a lustrous, creamy glaze, crackled with pink; a porcelain vase with brownish white glaze, strongly crackled (469); a porcelain vase in greenish white, with a compound crackle of black and red (470), a light-green porcelain vase (47I), and a greenish-white vase with black and gray crackles, forming a net-work (478 A).

Among the celadons the most noteworthy pieces are (480) a large vase with lotus-leaf raised decoration, in which the velvet like quality of the glaze is very striking; a delicately colored vase, very united in color effect (48I); a gourd shaped light-green vase, decorated with peonies in relief $(483)$, and a vase in which the green glaze is very warm and tender and the relief decorations have lntuc-leaf and scroll motives (478); a very pale vase, softly toned (498); a vase decorated with lace-work in white in slight relief (499); a vase with fluted body and scalloped rim and base (500), and two splendid vases with relief decorations (50I and 502). The Japanese celadon in this room does not lose by comparison with the Chinese. The lilac-colored monochromes, among them (No. 5I4) a lovely vase with a trumpet-neck, and (No. 5I6) a very imposing vase with bands in relief, are scarcely less beautiful than the jadelike celadons. The light blue porcelain vase (No. 520) and (No. 523) a tall vase, covered with a fine dark blue glaze are splendid examples.

A group which forms one of the strong points of the collection is that of the mirror blacks. There are four pieces of this rare and valuable ware, which is regarded by connoisseurs as being one of the highest developments of the Chinese keramic art. No. 507 is a jar-shaped vase with the black shot with dark green. No. 508, a vase, has violet in the black. No. 509, a porcelain vase, has small particles of gold in the rich glaze. No. 5 Io is somewhat similar in character. A vase of stoneware, covered with a dark green glaze, is said to be the oldest piece in the collection, dating back to $900 \mathrm{~A}$. D.

The case of polychromatics presents a most beautiful sight, from the depth of tone and richness and subtlety of color noticeable in its lustres,

\section{$449-231$
$456-216$}

$438-235$

$463-232$
$467-236$

$470-243$ 
which gleam with mysterious splendor in the 597-288 artificial light. A turquoise blue faience vase, covered with a yellow glaze spotted with large patches of liver color $(600)$, a stoneware vase 6/4-274 admirably toned (6I4); Nos. 632 and 633 , two vases, both with iron-red glazes with metallic spots; and a stoneware cup, with a band of green glaze round the rim, and enamel decorations (647) are among the treasures of this case. Other valuable polychromes are (556) a porcelain vase, covered with a yellow-speckled olive green glaze, and a stately vase of porcelain, covered with very dark green speckled glaze, which skilfully imitates patinated bronze. The vase has decorations in relief, such as are found on old bronze (557). No. 565 is a vase with lionhead handles, (584) a vase mottled with greenish white, claret-color and red, (585) a vase with a rich glaze of different colors, $(585)$ an incenseburner, (604) a porcelain dish, covered with lilac glaze, and decorated in a manner imitating crackle. Nos. 642 and 643 are a large blue porcelain vase and a large blue splash vase with the glaze clouded and flecked. No. 620 is a finely-toned mauve-colored glazed vase with white relief designs under the glaze.

The Kienyo tea bowls, of which there are nine, represent the most artistic achievements of the Chinese keramists, especially in the matter of glaze. These glazes are peculiarly subtle in color, with singular minglings of dark and light hues, toned into one perfect whole. They are marvels of duskv richnese of minr. No. 648 has a lustrous black glaze, with purple and blue tints. No. 650 has a hare skin glaze-that is, containing regular lines of pale silver. No. 654 has a beautiful black glaze, with spots of yellow with a pink and blue bloom. No. 655 has a brown glaze tinged with blue and red and having claret color designs, besides being glazed with claret color outside. These bowls are among the other pieces what pearls are among jewels.

$657-291$ In the class of blue and white porcelains may be mentioned No. 657, a fireholder, No. 659, a bowl, No. 674, a vase, No. 672 , a jar with lotusleaf cover, and the five vases, 684, 685, 686, 687 and 688, all of which show magnificent specimens of blue decoration under the glaze.

Among the many beautiful pieces of porcelain, painted with various colors under the glaze, the vase No. 723 and that 724 merit close study, as examples of old Chinese decoration. A lovely piece is a white vase with black designs of plum blossom and bamboo (727 A). A brilliant mass of color is formed by the collection of porcelains painted with colors over the glaze. No. 728 , a figure of the god Fukurokujin, No. 729 , a plate, a vase (734) and a jade-green cup with a gold scroll, are among the choicest pieces. A particularly fine example of enamel decoration is the large vase 743 . The four specimens of Boccaro ware, especially a teapot (774), and a ewer in the form of a lotus leaf (776), are interesting to the true amateur of keramics.

None of the wares are more individual and characteristic than the Korean. The Korean ivory-white porcelain is marvelously fine in paste and in quality of workmanship. No. 79I is an ivory-white vase with a trumpet-shaped neck and a decoration of incised leaves and tendrils. A rosy-toned, ivory-white stirrup cup (793) offers a beautiful example of the artistic merit of this ware. A wine cup in the form of a convolvulus flower, appropriately decorated and inscribed, is another marvel of delicate loveliness (795), and a cup in the shape of a lotus flower (794) is no less worthy the connoisseur's attention. The Koren: falencos aro vary uuivus. Tluy ung gest the Aztec potteries of Mexico in their forms and in color and style of decoration. The three large vases, 778,779 and 780 are remarkably decorative in color-effect and very original in design.

Some ancient pieces of stoneware and faience, made by Japanese keramists, in Korea, between I 596 and 1685 , bring the visitor to the end of this unequalled collection, which consists of 800 examples, each representing a distinct keramic principle.

Charlotte Adams. 
